\title{
Bacterial colonization of the freshwater planktonic diatom Fragilaria crotonensis
}

\author{
Petr Znachor*, Karel Šimek, Jiří Nedoma \\ Biology Centre of Czech Academy of Sciences, v.v.i., Institute of Hydrobiology, Na Sádkách 7, České Budějovice 37005, \\ Czech Republic
}

\begin{abstract}
In 2006, the seasonal course of bacterial colonization and silification rates of a colonial diatom Fragilaria crotonensis were studied at 2 distinct depths ('surface' $0.5 \mathrm{~m}$ and $\mathrm{Z}_{\mathrm{eu}}$, the depth of $1 \%$ remaining surface photosynthetically active radiation) in the eutrophic Rímov Reservoir (Czech Republic). In the study period (July to September), Fragilaria dominated the phytoplankton and formed remarkable subsurface peaks of biomass at $\mathrm{Z}_{\mathrm{eu}}$. Diatoms living under light-limited conditions at $Z_{\text {eu }}$ displayed lower silification rates measured with the fluorescence probe 2-(4-pyridyl)-5-\{[4-(2-dimethylaminoethyl-aminocarbamoyl)methoxy]phenyl\} oxazole (PDMPO) and were significantly more colonized by bacteria than at the surface (seasonal means 7.8 and 5.0 bacteria per Fragilaria cell, respectively). In 3 additional experiments using double-stained Fragilaria cells (PDMPO and 4', 6-diamidino-2-phenylindole [DAPI]), diatom cells with no PDMPO fluorescence were significantly more colonized by bacteria regardless of the depth, indicating that bacterial colonization reflects the physiological state of the diatoms. As an apparent consequence of a flood event in August, the Fragilaria assemblage was composed of 2 temporally isolated subpopulations differing markedly in the cell length, cell surface area and extent of bacterial colonization. Although both Fragilaria sub-populations showed similar silification rates, the late summer (post-flood) Fragilaria sub-population with smaller cells showed a significantly lower bacterial colonization, while the difference in bacterial colonization between the depths remained consistently significant throughout the study. Our results imply that bacterial colonization of diatom cell surfaces is modulated by both diatom growth and changes in population structure over the season.
\end{abstract}

KEY WORDS: Fragilaria crotonensis - Diatoms - Bacterial colonization - Physiological state · Silification · PDMPO

\section{INTRODUCTION}

Phytoplankton cells represent an important bacterial habitat that is markedly distinct from the surrounding water (Bell \& Mitchell 1972). Diatoms are frequently colonized by bacteria (Cole 1982, Vaqué et al. 1989, 1990, Bidle \& Azam 1999, Grossart et al. 2005), sessile bacterivorous choanoflagellates (Šimek et al. 2004) or freshwater chytridiomycetes (Wurzbacher et al. 2010). Notably, diatoms are frequently the key component of phyto- plankton assemblages (Armbrust 2009), responsible for 20 to $25 \%$ of global carbon fixation (Smetacek 1999), and serve as the basis for pelagic food webs. There is a multitude of possible interactions between planktonic diatoms and bacteria colonizing their frustules (Cole 1982, Grossart et al. 2005, Grossart \& Simon 2007). The dynamics of bacteria and diatom assemblages are thought to be closely linked, and thus, their interplay markedly affects the functioning of the pelagic microbial food web (Cole 1982, Simon et al. 2002). The abundance and 
activity of bacteria colonizing diatom cells have been found to alter diatom sinking properties due to excessive production of exopolymeric substances, which increase diatom aggregation and thus the removal of organic matter from the water column (Grossart et al. 2006).

Variability in bacterial colonization appears to be closely dependent on diatom population dynamics and physiological state because increased numbers of attached bacteria coincide with late senescent stages of diatom blooms, while in early stages, bacterial colonization is generally low (Middelboe et al. 1995, Riemann et al. 2000, Grossart et al. 2005). However, there are some contradictory reports on the high abundance of attached bacteria on actively growing diatom cells (Smith et al. 1995) and low colonization in the late phase of a batch culture experiment (Kaczmarska et al. 2005). Current knowledge of bacteria-diatom interactions is based on indirect evidence without direct examination of the diatom physiological state and growth activity. Both might be highly variable at population or individual cell levels, even if these cells are in the same colony (Znachor \& Nedoma 2008).

Various modes of bacteria-diatom interactions can be described in terms of general ecological concepts: (1) Competition - bacteria compete with diatoms for inorganic nutrients (Bratbak \& Thingstad 1985); (2) Commensalism - bacteria benefit from diatoms without having any negative effect on them. Nonetheless, bacterial commensalism may switch to parasitism, particularly when diatoms grow under environmental stress (Cole 1982); (3) Parasitismbacteria either invade the host cell or produce metabolites with algicidal activity, both leading eventually to cell lysis and death (Imai et al. 1993, Park et al. 2010). In contrast, diatoms can inhibit bacterial growth by producing antibiotic compounds (Leflaive \& Ten-Hage 2009) (4) Mutualism - bacteria benefit from diatom exudates (Pete et al. 2010), whereas diatoms profit from bacterial products, such as vitamins or other growth factors or recycling of limiting nutrients (Croft et al. 2005, Droop 2007).

To date, studies addressing bacteria-diatom interactions have been performed either in marine systems or predominantly marine diatom cultures, while there are only a very few reports for freshwater diatoms. Under favourable conditions, marine diatoms dramatically increase in cell numbers, i.e. by several orders of magnitude in just few days (Tsuda et al. 2003, Armbrust 2009, Iluz et al. 2009), and thus, growth activity might be deduced from rapid changes in pigment concentration or diatom abun- dance comparable to culture experiments (Grossart et al. 2005). However, in freshwater lakes or reservoirs, diatoms can dominate the phytoplankton for months (Middelboe et al. 1995, Znachor et al. 2008), and therefore, to assess diatom physiological status, algal growth activity must be directly examined (Znachor \& Nedoma 2008).

Recently, the fluorescence probe PDMPO, i.e. 2-(4pyridyl)-5-\{[4-(2-dimethylaminoethyl-aminocarbamoyl)methoxy]phenyl\} oxazole, has been employed to measure silica deposition in the summer diatom assemblage at various depths in the eutrophic Rímov Reservoir (Czech Republic; Znachor \& Nedoma 2008, Znachor et al. 2008). During these experiments, the diatom assemblage was exclusively dominated by Fragilaria crotonensis, which formed pronounced peaks of biomass at the base of the euphotic zone $\left(Z_{\text {eu }}, 2\right.$ to $\left.6.5 \mathrm{~m}\right)$. At $Z_{\text {eu, }}$ silica deposition was found to be significantly constrained by low light availability, while at the surface, it was limited by phosphorus deficiency; the effect of dissolved Si was not statistically significant (Znachor \& Nedoma 2008). Extreme rainfalls were shown to have a crucial effect on the dynamics of the diatom assemblage: a marked increase in $\mathrm{Si}$ deposition rates was reported just after the summer storm event, consequently followed by an increase of Fragilaria abundance (Znachor et al. 2008). Because Fragilaria recurrently dominates summer phytoplankton in the Rímov Reservoir, it has been also used as a model organism for studying phytoplankton osmotrophy (Znachor \& Nedoma 2010). It was found, however, that the phytoplankton uptake of ${ }^{3} \mathrm{H}$-glucose was very low, which contrasted with the high uptake rate observed for Fragilariaassociated bacteria (Znachor \& Nedoma 2010).

In the present study, we investigate the relationship between the bacterial colonization and growth activity of diatoms on both individual cell and the whole diatom population levels. While a part of these data has been previously used in different context, e.g. as variables documenting seasonal changes in Fragilaria silification rates (Znachor et al. 2008) or factors affecting diatom silification at various depths (Znachor \& Nedoma 2008), our present study has a quite distinct focus. Here, we provide compelling field evidence of an inverse relationship between the bacterial colonization of a freshwater diatom, which dominated the phytoplankton community during summer, and its growth activity deduced from silification rates. In addition, we found a significant relation between seasonal changes in bacterial colonization and variation in Fragilaria cell dimensions. 


\section{MATERIALS AND METHODS}

\section{Study site and sampling design}

Our study was conducted in the dam area of the dimictic, meso-eutrophic Ř́mov Reservoir (Czech Republic; $48^{\circ} 50^{\prime} 56^{\prime \prime} \mathrm{N}, 14^{\circ} 29^{\prime} 26^{\prime \prime} \mathrm{E}_{\text {; }} 470 \mathrm{~m}$ a.s.l.; area, $2.06 \mathrm{~km}^{2}$; volume, $34.5 \times 10^{6} \mathrm{~m}^{3}$; length, $13.5 \mathrm{~km}$; max. depth, $43 \mathrm{~m}$; mean depth, $16.5 \mathrm{~m}$; mean retention time, $100 \mathrm{~d}$ ). From July to September 2006 , we took samples from the surface $(0.5 \mathrm{~m})$ and the depth of $1 \%$ surface irradiance $\left(\mathrm{Z}_{\mathrm{eu}}, 2\right.$ to $\left.6.5 \mathrm{~m}\right)$ at weekly intervals to assess the abundance of total and diatom-associated bacteria along with the phytoplankton composition and physiological state.

\section{Background limnological data}

Vertical profiles of photosynthetically active radiation (PAR) necessary for estimation of the euphoticzone depth $\left(\mathrm{Z}_{\text {eu }}\right)$ were obtained using a LI-COR
LI-1400 datalogger with a spherical quantum underwater sensor LI $193 \mathrm{SA}$ (LI-COR). Samples for phytoplankton cell counts were taken with a Friedinger sampler and preserved with a Lugol solution. Phytoplankton were enumerated employing the Utermöhl method on an Olympus IMT-2 inverted microscope (Olympus; Lund et al. 1958).

\section{Assessment of Fragilaria growth activity}

During the study period, the phytoplankton community was prevalently dominated by the colonial diatom Fragilaria crotonensis (Znachor \& Nedoma 2008), which formed remarkable subsurface peaks of biomass at $Z_{\text {eu }}$ (often identical with the depth of the metalimnion) due to cell accumulation above the density gradient (Znachor et al. 2008). To assess Fragilaria growth activity, we used a $24 \mathrm{~h}$ incubation with PDMPO, a specific tracer for biogenic Si deposition (Shimizu et al. 2001). PDMPO quickly enters diatom cells and is co-deposited with silica into the

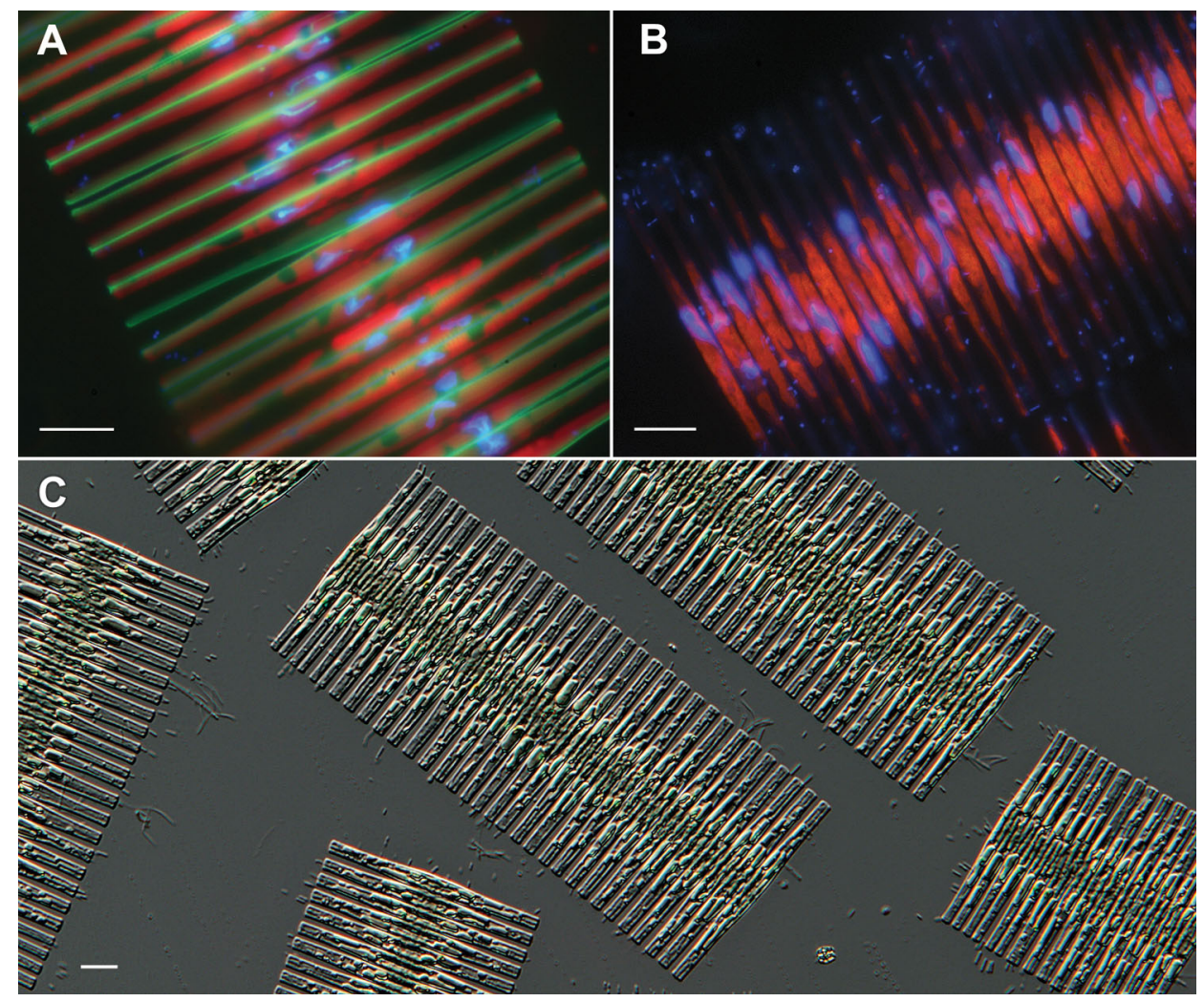

Fig. 1. Composite fluorescence image of double-stained diatoms. At the surface, (A) Fragilaria colonies actively depositing Si were without a substantial population of attached bacteria, while (B) those colonies inhabiting the metalimnion were often non-active and showed dense bacterial colonization. Green fluorescence is PDMPO incorporation indicating diatom growth, blue objects are DAPI-stained bacteria and diatom cell nuclei, and red is chlorophyll autofluorescence. Panel C provides an overall view of Fragilaria colonies using a Nomarski contrast technique. Scale bars $=10 \mu \mathrm{m}$ 
newly synthesized frustule, yielding a bright green fluorescence (Shimizu et al. 2001). Application of this epifluorescence microscopy technique enables a simple distinction between cells within diatom colonies and populations that are actively depositing $\mathrm{Si}$ and those that are not (Leblanc \& Hutchins 2005; Fig. 1). In addition, PDMPO fluorescence has been shown to be proportional to the amount of $\mathrm{Si}$ deposited (Leblanc \& Hutchins 2005), and thus, it provides a useful indirect measure of the rate of recruitment of new cells and, therefore, may be used as a quantitative proxy for diatom growth (Znachor \& Nedoma 2008). Both the PDMPO fluorescence intensity expressed as relative fluorescence units (FU) and the Fragilaria cell dimensions were quantified by image analysis as described by Znachor \& Nedoma (2008). Briefly, samples were incubated for $24 \mathrm{~h}$ in $50 \mathrm{ml}$ quartz glass bottles in situ at both the surface and $\mathrm{Z}_{\text {eui }}$ the PDMPO (final concentration of 0.125 $\mu \mathrm{mol} \mathrm{l}^{-1}$; Molecular Probes) was added at the beginning of the incubation. Samples were filtered through $10 \mu \mathrm{m}$ polycarbonate filters immediately after the incubation and transported to the laboratory for fluorescence measurements. Filters were rinsed with distilled water to eliminate any unbound PDMPO and inspected using epifluorescence microscopy. PDMPO fluorescence was measured $30 \mathrm{~min}$ after the filter preparation using image cytometry; 50 diatom colonies were measured from each sample (magnification 200x). Each image file consisted of 2 meshed 8-bit individual monochromatic images of an identical microscope field taken with a PDMPOspecific filter-cube (excitation/emission: 360-370 $\mathrm{nm} / 520-540 \mathrm{~nm}$ ) for quantification of the PDMPO fluorescence and a chlorophyll autofluorescence image (excitation/emission: 510-550 nm/>590 nm) for localization of Fragilaria colonies and cell dimension measurements. An image analysis system consisting of a Nikon Eclipse 90i fluorescence microscope (Nikon; Nikon Plan Fluor 20×, Nikon Plan Apo 100x), a monochromatic digital integrating camera (VDF Voskühler) and an NIS-Elements 3.0 PC-based image analysis software (Laboratory Imaging) was used. The surface area of Fragilaria cells was calculated from mean cell dimensions by approximation to an elliptic prism (Hillebrand et al. 1999).

\section{Bacterial enumeration}

Seasonal changes in the numbers of total and Fragilaria-associated bacteria at the surface and $\mathrm{Z}_{\mathrm{eu}}$ were obtained by bacterial counts after 4',6-diamidino-2- phenylindole (DAPI) staining (Porter \& Feig 1980) of PDMPO untreated samples on 0.2 (total bacteria) and $2 \mu \mathrm{m}$ (diatom-attached bacteria) pore-size Poretics filters (Osmonics, Poretics), respectively. Both total and diatom-attached bacteria were counted under 1000x magnification. The vast majority of the attached bacteria was clearly focused on several optical planes and counted at planes clearly different from surface of the $2 \mu \mathrm{m}$ pore-size filter where the free-living bacteria might eventually be left after a gentle rinsing prior to counting. Careful focusing at different planes allows for counting of the attached bacteria on both sides of diatom frustules because the frustules are semi-transparent in the DAPI-stained preparations. At least 500 bacterial cells were counted for total bacterial counts, and 50 diatom colonies (200 to 400 individual cells) were inspected for diatom-attached bacterial abundance. Additionally, in 3 parallel experiments in July, bacteria attached on Fragilaria were counted after a $24 \mathrm{~h}$ incubation with PDMPO. This allowed for a direct estimation of bacterial colonization of Fragilaria cells with contrasting Si deposition rates at a particular depth (Fig. 1).

\section{Statistical analysis}

All measurements were made in duplicate. Statistical treatment of the data was done using Prism 5 (GraphPad Software). A 2-way ANOVA was performed to examine differences in the measured parameters with (1) depth and (2) sampling period. Unpaired $t$-tests were used to test differences in bacterial colonization of Fragilaria cells after double staining with DAPI and PDMPO.

\section{RESULTS}

The bacteria attached on Fragilaria at the surface and $Z_{\text {eu }}$ represented only a small portion of the total bacteria (seasonal average 2.3 and $2.9 \%$, respectively; Table 1). Temporal changes in bacterial colo-

Table 1. Total numbers of Fragilaria-attached and total bacteria per ml (seasonal mean values with ranges, $\times 10^{6} \mathrm{ml}^{-1}$ )

\begin{tabular}{|lcccc|}
\hline Depth & \multicolumn{2}{c|}{$\begin{array}{c}\text { Fragilaria-attached } \\
\text { bacteria } \\
\end{array}$} & \multicolumn{2}{c|}{ Total bacteria } \\
& Mean & Range & Mean & Range \\
\hline Surface & 0.07 & $0.001-0.35$ & 3.55 & $2.29-4.81$ \\
$\mathrm{Z}_{\text {eu }}$ & 0.11 & $0.001-0.32$ & 3.31 & $1.06-5.24$ \\
\hline
\end{tabular}




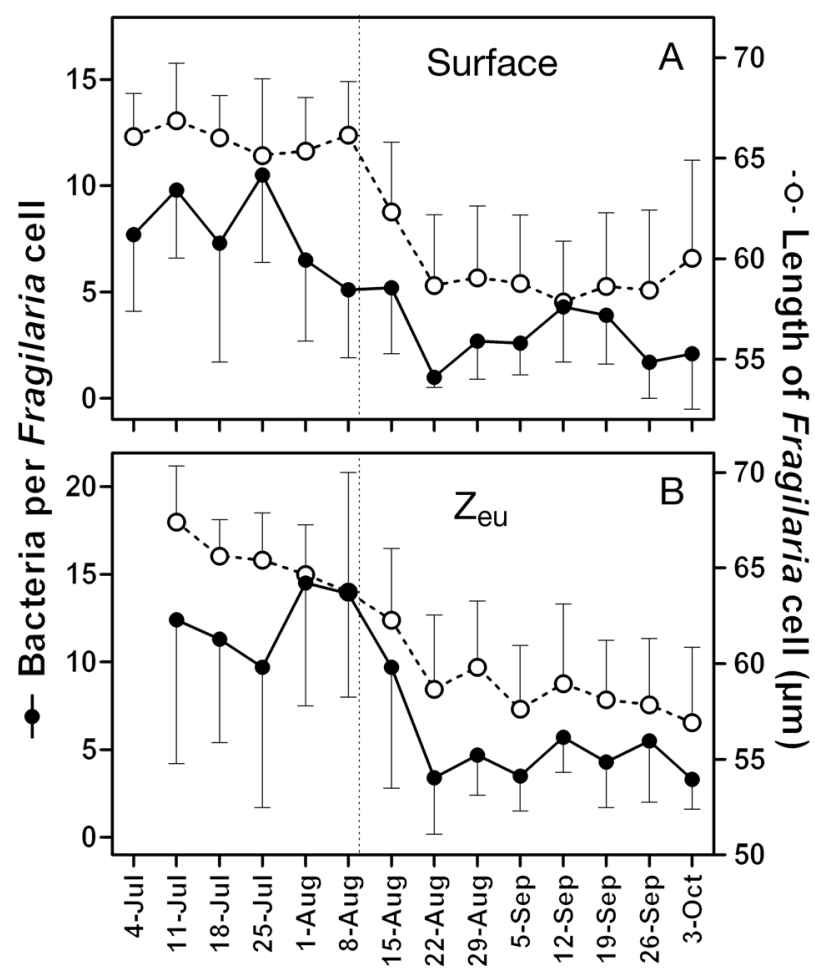

Fig. 2. Seasonal course of bacterial colonization of Fragilaria cells and their length at 2 depths. Over the season, 2 Fragilaria sub-populations developed, differing markedly in cell size and the extent of bacterial colonization. Seasonal courses of both parameters were highly correlated (surface, $\mathrm{r}^{2}=0.70, \mathrm{p}<0.001 ; \mathrm{Z}_{\mathrm{eu}}, \mathrm{r}^{2}=0.79, \mathrm{p}<0.001$, linear regression). Vertical dotted lines indicate flood event. Means \pm SD

nization of Fragilaria and diatom cell length at the surface and $Z_{\text {eu }}$ are given in Fig. 2. The seasonal courses of colonization were characterized by (1) higher numbers of Fragilaria-associated bacteria at $\mathrm{Z}_{\text {eu }}$ than at the surface ( 7.8 and 5 bacteria per Fragilaria cell, respectively) and (2) an abrupt decrease in bacterial colonization in the second part of the study period observed at both depths. The depth-related difference reflected Fragilaria growth activity measured by PDMPO fluorescence, which was much lower at $Z_{\text {eu }}$ than at the surface, while the seasonal decrease in bacterial colonization was related to a change in Fragilaria cell dimensions (Fig. 3). The effects of both depth and season were highly significant ( $p<0.0001,2$-way ANOVA; Fig. 3A,C).

Both the silification rates and portions of Fragilaria cells actively depositing $\mathrm{Si}$ were markedly lower at $\mathrm{Z}_{\text {eu }}\left(\mathrm{PAR}, 4\right.$ to $100 \mathrm{~W} \mathrm{~m}^{-2} \mathrm{~d}^{-1}$ ) than at the surface (PAR, 1102 to $8586 \mathrm{~W} \mathrm{~m}^{-2} \mathrm{~d}^{-1}$; 2-way ANOVA, $\mathrm{p}<0.0001$; Fig. 3E,F). To obtain direct evidence that bacterial colonization is negatively related to Fragilaria growth activity even under the same light conditions, DAPI- stained bacteria were counted on diatoms previously incubated with PDMPO (Fig. 1). Regardless of depth, Fragilaria cells actively depositing Si showed a significantly lower bacterial colonization than slow-growing or senescent cells without any measurable Si deposition $(\mathrm{p}<0.001$; Fig. 4). This indicates that the depth-related differences in the per-cell colonization of Fragilaria by bacteria resulted from a variable proportion of Si-depositing diatom cells rather than from changing silification rates.

Fragilaria assemblages were composed of 2 temporally isolated sub-populations differing markedly in cell length, cell surface area and extent of bacterial colonization (Figs. $2 \& 3$ ). The reasons for such a dramatic mid-summer decrease in Fragilaria cell length are still unknown; however, a sudden disturbance in the form of a flood event might be a plausible explanation. An extreme rainfall (7-8 August) substantially increased the flushing rate, disrupted the thermal stratification, temporarily altered the nutrient and light availability (Znachor et al. 2008) and apparently also caused a discontinuity in the seasonal course of Fragilaria population dynamics. Although both Fragilaria sub-populations showed similar silification rates $(\mathrm{p}>0.35,2$-way ANOVA; Fig. 3E,F), the late summer Fragilaria sub-population with smaller cells (pooled data from both depths: pre-flood $65.6 \mu \mathrm{m}$, post-flood $58.9 \mu \mathrm{m}_{i} \mathrm{p}<0.0001$, 2-way ANOVA; Fig. 3B) was significantly less colonized by bacteria ( $\mathrm{p}<0.0001,2$-way ANOVA; Fig. 3A,C), suggesting that other factors besides growth and physiological state can be involved in the bacterial colonization of diatoms. Notably, nutrient concentrations dropped within $\sim 2 \mathrm{wk}$ after the flood to previous values (soluble reactive phosphorus $\sim 4.5 \mu \mathrm{g} \mathrm{l}^{-1}$, nitrates $\sim 1 \mathrm{mg} \mathrm{l}^{-1}$; Znachor et al. 2008).

\section{DISCUSSION}

The depth-related differences in the bacterial colonization of Fragilaria cells obviously reflected the different physiological states and growth activity of the respective diatom populations. At $\mathrm{Z}_{\text {eu }}$ the Fragilaria growth was constrained by low light availability; the diatom cells were narrower and contained more chlorophyll, and the cell number of the Fragilaria colonies was lower than at the surface, as reported in the parallel study (Znachor \& Nedoma 2008). It has been shown that when diatom growth is slow, algal surfaces are exposed to bacterial colonization for a longer time, leading to higher bacterial colonization than on fast-growing cells (Vaqué et al. 1990). 


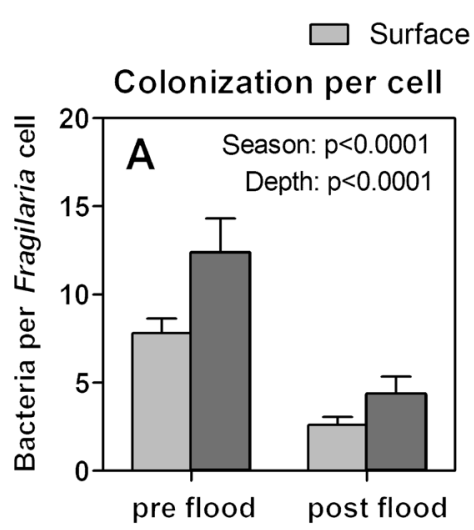

$\square \mathrm{Z}_{\mathrm{eu}}$
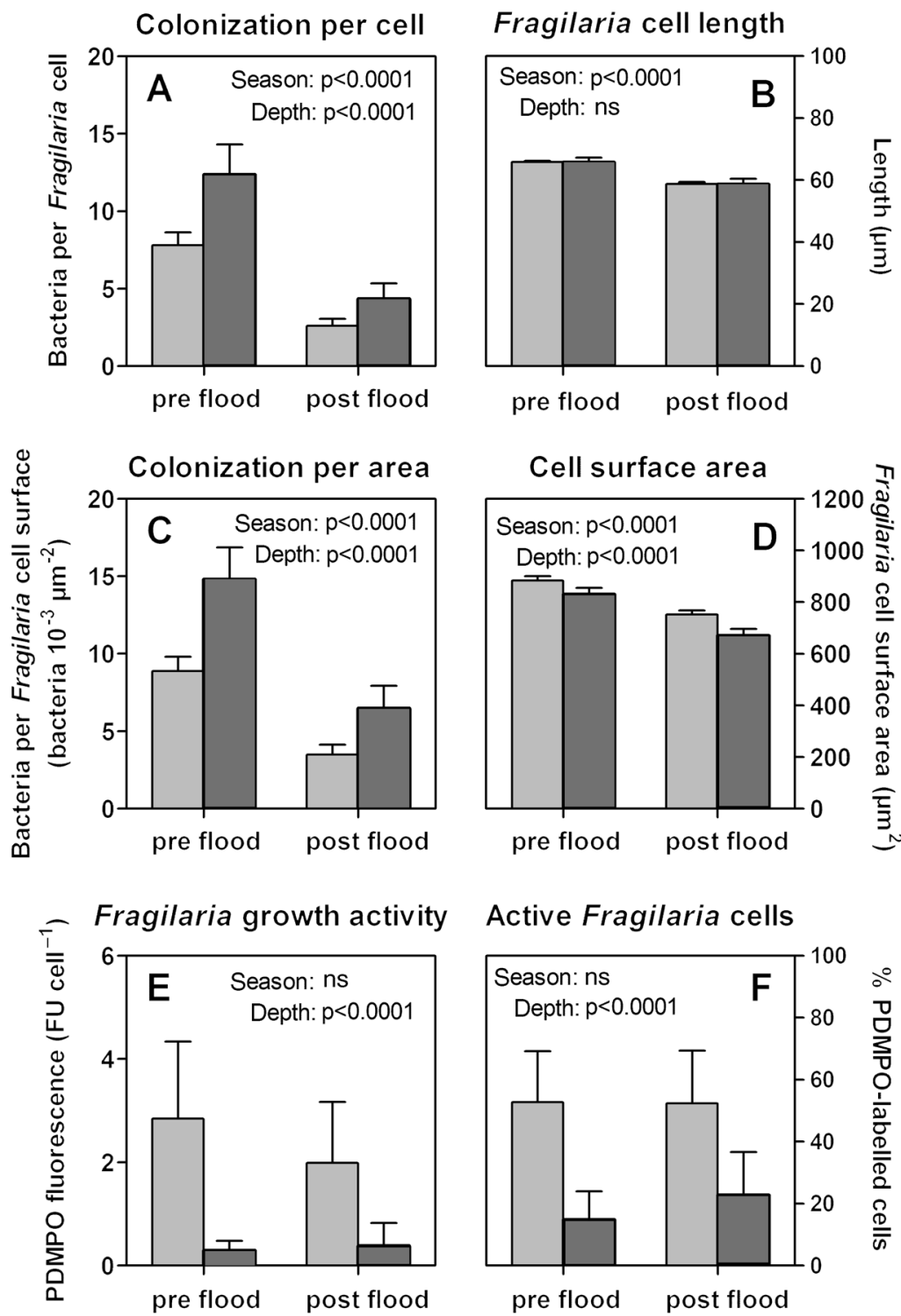

Fig. 3. Effect of flood event (season) and depth on $(A, C)$ bacterial colonization of Fragilaria, (B,D) diatom cell dimensions and $(\mathrm{E}, \mathrm{F})$ growth activity estimated with PDMPO technique. Statistical significance was tested with 2-way ANOVA. Means $\pm \mathrm{SD}$

Additionally, bacterial attachment to phytoplankton depends on encounter probability, which increases with the abundance of both bacteria and diatom cells in water and also with algal size (Vaqué et al. 1989). In the present study, we did not find any relationship between total bacterial abundance and the degree of diatom colonization at both depths. Larger diatom species have been reported to support more abundant bacterial colonisers than smaller ones (Vaqué et al. 1990). The same is true for bacterial colonization of dispersed water particles. In Lake Con-

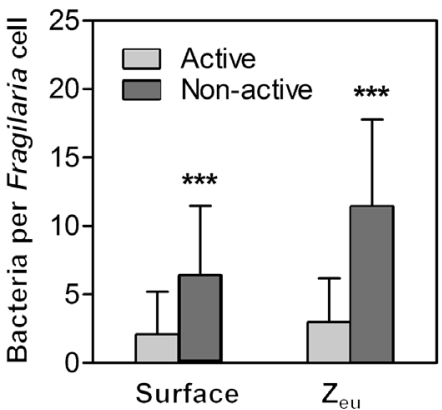

Fig. 4. Mean $( \pm \mathrm{SD})$ numbers of bacteria per Fragilaria cell from 3 measurements conducted in July 2006. Bacteria were counted after double staining with PDMPO and DAPI, allowing direct estimation of diatom activity in Si deposition. Fragilaria cells actively depositing $\mathrm{Si}$ (labelled with PDMPO) were significantly less colonized by bacteria than non-labelled cells regardless of the depth. ${ }^{* *}$ Significant differences $(\mathrm{p}<0.0001, t$-test) between active and non-active Fragilaria cells

stance, Grossart \& Simon (1998) found that the abundance of particle-associated bacteria increased with depth, mainly due to larger aggregates. Generally, attached bacterial abundance tends to increase with increasing size of diatom aggregates (Ploug \& Grossart 2000), detritus particles (Luef et al. 2007) or transparent exopolymeric particles (Pedrotti et al. 2009), which can be formed from precursors released by diatoms (Simon et al. 2002, Pedrotti et al. 2009).

In our study, the seasonal decrease in bacterial colonization (by $\sim 60 \%$, Fig $3 \mathrm{~A}, \mathrm{C}$ ) observed after the flood event was not proportional to the reduction in Fragilaria cell length (by $\sim 11 \%$; Fig. 3B) and consequently cell surface area (by $\sim 17 \%$; Fig. 3D), and the total bacterial counts were virtually unaffected by the flood (pooled average from both depths: pre-flood $3.26 \times 10^{6} \mathrm{ml}^{-1}$, postflood $3.34 \times 10^{6} \mathrm{ml}^{-1}$ ). This implies that bacterial colonization is modulated by intervening factors affected by the flood event and not only by the encounter probability. In the post-flood period, weak thermal stratification produced by cold and windy weather (Znachor et al. 2008) and a decrease in temperature (pooled data from both depths: pre-flood $21.2^{\circ} \mathrm{C}$, post-flood $17.5^{\circ} \mathrm{C}_{i} \mathrm{p}<$ 0.001) might account for the low numbers of bacteria attached to Fragilaria cells. A similar pattern has been found for bacterial colonization of transparent exopolymeric particles in Lake Pavin (Arnous et al. 2010). Additionally, both Fragilaria sub-populations 
may have differed in specific modes of interactions with bacteria, supposedly resulting from e.g. a seasonal shift in bacterial community composition (Grossart et al. 2005), the distinct quantity and quality of exudates (Pete et al. 2010), varying composition of the organic matrix protecting diatom frustules or from generally different susceptibility to bacterial colonization under changing environmental constraints. However, besides the season-related shift in factors such as temperature and light intensity, we have no direct indication of which controlling factors prevailed in the present study.

Despite a low relative abundance of Fragilaria-associated bacteria (Table 1), they supposedly played an important role in the transformation of organic carbon. This notion is supported by a combination of the data presented here with those of a follow-up study (Znachor \& Nedoma 2010), where microautoradiography and size fractionation were applied to study carbon flows within pelagic food webs in the Rímov Reservoir. The bacteria attached to Fragilaria accounted for $15 \%$ of the overall ${ }^{3} \mathrm{H}$-glucose uptake, while free-living bacteria accounted for $75 \%$ (Znachor \& Nedoma 2010). Thus, diatom-associated bacteria could account for a much higher fraction of total glucose uptake than predicted based on their abundance, indicating higher cell-specific glucose uptake rates than for free-living bacteria. Assuming similar proportions of free-living and Fragilaria-associated bacteria in 2006 and 2007, Fragilaria-associated bacteria could exhibit, on average, $\sim 8$-fold higher cell-specific uptake rates of glucose than free-living bacteria. This is in accordance with a commonly accepted concept that diatom colonies and their attached bacteria represent true microbial 'hot spots', which are also characterized by high bacterial production and ectoenzymatic activities (Simon et al. 2002).

Bacteria colonizing diatom cells might benefit from their host by several means. It is well known that diatom exudation, which markedly increases under growth-limiting conditions, supports bacterial growth (Pete et al. 2010). When environmental stress exceeds the ecological tolerance of the algae, diatom cells start to decompose, and as a result, organic-rich cell constituents are liberated (Franklin et al. 2006). Thus, bacteria directly attached to diatom cells can utilize the released organic compounds, allowing them to display generally higher growth rates than free-living bacteria (Simon 1987). Moreover, diatom-attached bacteria preferentially utilize the algal exudates, which limits the availability of the exudates for freeliving bacteria. In addition, surface attachment and embedding into an organic matrix has been sug- gested as an alternative mechanism for bacteria to avoid predation pressure by typical planktonic suspension-feeding flagellates (Pernthaler 2005). Such amorphous extracellular polymers were also observed in the present after DAPI staining; however, we were not able to accurately quantify them.

Besides these specific algal-bacterial interactions, almost all of the bigger diatom colonies in our experiments were observed to also anchor bacterivorous choanoflagellates (data not shown). When these diatom-associated bacterivores become abundant, they can significantly contribute to the overall mortality rates of free-living bacterioplankton (Šimek et al. 2004), creating an alternative pathway of organic carbon to higher trophic levels. Thus, on the micro scale, both the processes of diatom cell surface colonization and intensive bacterivory apparently create hot spots of microbial activities, accelerate nutrient recycling and, therefore, affect overall nutrient availability in aquatic systems.

In summary, using a sensitive, fluorescence-based approach, this study has brought new insights into factors affecting the bacterial colonization of Fragilaria studied at both single-cell and population levels in a natural aquatic system. Diatom growth activities and changes in population structure modulate the dynamics of bacterial populations on diatom cell surfaces. With respect to the large diatom biomass over a significant part of the season, diatom colonies represent hot spots of microbial interactions and activities in the water column of eutrophic freshwater reservoirs.

Acknowledgements. This study was largely supported by the Grant Agency of the Czech Republic under research grants 206/08/0015, P504/11/2177, P504/11/2182 and AV0Z60170517. We thank H. P. Grossart and 3 anonymous reviewers for their valuable comments on an earlier version of the manuscript. Language correction was made by Keith Edwards.

\section{LITERATURE CITED}

Armbrust EV (2009) The life of diatoms in the world's oceans. Nature 459:185-192

Arnous MB, Courcol N, Carrias JF (2010) The significance of transparent exopolymeric particles in the vertical distribution of bacteria and heterotrophic nanoflagellates in Lake Pavin. Aquat Sci 72:245-253

Bell W, Mitchell R (1972) Chemotactic and growth responses of marine bacteria to algal extracellular products. Biol Bull (Woods Hole) 143:265-277

Bidle KD, Azam F (1999) Accelerated dissolution of diatom silica by marine bacterial assemblages. Nature 397: 508-512

Bratbak G, Thingstad TF (1985) Phytoplankton-bacteria interactions: an apparent paradox? Analysis of a model system with both competition and commensalism. Mar Ecol Prog Ser 25:23-30 
Cole JJ (1982) Interactions between bacteria and algae in aquatic ecosystems. Annu Rev Ecol Syst 13:291-314

- Croft MT, Lawrence AD, Raux-Deery E, Warren MJ, Smith AG (2005) Algae acquire vitamin B-12 through a symbiotic relationship with bacteria. Nature 438:90-93

Droop MR (2007) Vitamins, phytoplankton and bacteria: symbiosis or scavenging? J Plankton Res 29:107-113

Franklin DJ, Brussaard CPD, Berges JA (2006) What is the role and nature of programmed cell death in phytoplankton ecology? Eur J Phycol 41:1-14

Grossart HP, Simon M (1998) Bacterial colonization and microbial decomposition of limnetic organic aggregates (lake snow). Aquat Microb Ecol 15:127-140

Grossart HP, Simon M (2007) Interactions of planktonic algae and bacteria: effects on algal growth and organic matter dynamics. Aquat Microb Ecol 47:163-176

Grossart HP, Levold F, Allgaier M, Simon M, Brinkhoff T (2005) Marine diatom species harbour distinct bacterial communities. Environ Microbiol 7:860-873

> Grossart HP, Czub G, Simon M (2006) Algae-bacteria interactions and their effects on aggregation and organic matter flux in the sea. Environ Microbiol 8:1074-1084

> Hillebrand $\mathrm{H}$, Durselen CD, Kirschtel D, Pollingher $\mathrm{U}$, Zohary T (1999) Biovolume calculation for pelagic and benthic microalgae. J Phycol 35:403-424

> Iluz D, Dishon G, Capuzzo E, Meeder E and others (2009) Short-term variability in primary productivity during a wind-driven diatom bloom in the Gulf of Eilat (Aqaba). Aquat Microb Ecol 56:205-215

Imai I, Ishida Y, Hata Y (1993) Killing of marine phytoplankton by a gliding bacterium Cytophaga sp., isolated from the coastal Sea of Japan. Mar Biol 116:527-532

- Kaczmarska I, Ehrman JM, Bates SS, Green DH, Leger C, Harris J (2005) Diversity and distribution of epibiotic bacteria on Pseudonitzschia multiseries (Bacillariophyceae) in culture, and comparison with those on diatoms in native seawater. Harmful Algae 4:725-741

- Leblanc K, Hutchins DA (2005) New applications of a biogenic silica deposition fluorophore in the study of oceanic diatoms. Limnol Oceanogr Methods 3:462-476

- Leflaive J, Ten-Hage L (2009) Chemical interactions in diatoms: role of polyunsaturated aldehydes and precursors. New Phytol 184:794-805

Luef B, Aspetsberger F, Hein T, Huber F, Peduzzi P (2007) Impact of hydrology on free-living and particle-associated microorganisms in a river floodplain system (Danube, Austria). Freshw Biol 52:1043-1057

> Lund JWG, Kipling C, Le Cren ED (1958) The inverted microscope method of estimating algal numbers and the statistical basis of estimation by counting. Hydrobiologia 11:143-170

Middelboe M, Søndergaard M, Letarte Y, Borch NH (1995) Attached and free-living bacteria: production and polymer hydrolysis during a diatom bloom. Microb Ecol 29: 231-248

- Park JH, Yoshinaga I, Nishikawa T, Imai I (2010) Algicidal bacteria in particle-associated form and in free-living form during a diatom bloom in the Seto Inland Sea, Japan. Aquat Microb Ecol 60:151-161

- Pedrotti ML, Beauvais S, Kerros ME, Iversen K, Peters F (2009) Bacterial colonization of transparent exopolymeric particles in mesocosms under different turbulence inten-

Editorial responsibility: Staffan Kjelleberg,

Sydney, Australia sities and nutrient conditions. Aquat Microb Ecol 55: 301-312

Pernthaler J (2005) Predation on prokaryotes in the water column and its ecological implications. Nat Rev Microbiol 3:537-546

Pete R, Davidson K, Hart MC, Gutierrez T, Miller AEJ (2010) Diatom derived dissolved organic matter as a driver of bacterial productivity: the role of nutrient limitation. $\mathrm{J}$ Exp Mar Biol Ecol 391:20-26

$>$ Ploug H, Grossart HP (2000) Bacterial growth and grazing on diatom aggregates: respiratory carbon turnover as a function of aggregate size and sinking velocity. Limnol Oceanogr 45:1467-1475

> Porter KG, Feig YS (1980) The use of DAPI for identifying and counting aquatic microflora. Limnol Oceanogr 25: 943-948

> Riemann L, Steward GF, Azam F (2000) Dynamics of bacterial community composition and activity during a mesocosm diatom bloom. Appl Environ Microbiol 66:578-587

Shimizu K, Del Amo Y, Brzezinski MA, Stucky GD, Morse DE (2001) A novel fluorescent silica tracer for biological silicification studies. Chem Biol 8:1051-1060

Šimek K, Jezbera J, Horňák K, Vrba J, Sed'a J (2004) Role of diatom-attached choanoflagellates of the genus Salpingoeca as pelagic bacterivores. Aquat Microb Ecol 36: $257-269$

Simon M (1987) Biomass and production of small and large free-living and attached bacteria in Lake Constance. Limnol Oceanogr 32:591-607

Simon M, Grossart HP, Schweitzer B, Ploug H (2002) Microbial ecology of organic aggregates in aquatic ecosystems. Aquat Microb Ecol 28:175-211

Smetacek V (1999) Diatoms and the ocean carbon cycle. Protist 150:25-32

> Smith DC, Steward GF, Long RA, Azam F (1995) Bacterial mediation of carbon fluxes during a diatom bloom in a mesocosm. Deep-Sea Res Part I 42:75-97

- Tsuda A, Takeda S, Saito H, Nishioka J and others (2003) A mesoscale iron enrichment in the western Subarctic Pacific induces a large centric diatom bloom. Science 300:958-961

> Vaqué D, Duarte CM, Marrasé C (1989) Phytoplankton colonization by bacteria: encounter probability as a limiting factor. Mar Ecol Prog Ser 54:137-140

> Vaqué D, Duarte CM, Marrasé C (1990) Influence of algal population dynamics on phytoplankton colonization by bacteria: evidence from two diatom species. Mar Ecol Prog Ser 65:201-203

Wurzbacher CM, Barlocher F, Grossart HP (2010) Fungi in lake ecosystems. Aquat Microb Ecol 59:125-149

- Znachor P, Nedoma J (2008) Application of the PDMPO technique in studying silica deposition in natural populations of Fragilaria crotonensis (Bacillariophyceae) at different depths in a eutrophic reservoir. J Phycol 44: 518-525

> Znachor P, Nedoma J (2010) Importance of dissolved organic carbon for phytoplankton nutrition in a eutrophic reservoir. J Plankton Res 32:367-376

- Znachor P, Zapomělová E, Řeháková K, Nedoma J, Šimek K (2008) The effect of extreme rainfall on summer succession and vertical distribution of phytoplankton in a lacustrine part of a eutrophic reservoir. Aquat Sci 70:77-86 